\title{
INVENTARISASI EKTOPARASIT PADA BENIH IKAN LELE SANGKURIANG (Clarias gariepinus)
}

\author{
Wahyu Hidayat ${ }^{1}$, Mulyana $^{2}$, Fia Sri Mumpuni ${ }^{2}$ \\ ${ }^{1}$ Mahasiswa S1 Program Studi Akuakultur, Fakultas Pertanian, Universitas Djuanda Bogor \\ ${ }^{2}$ Staf Pengajar Program Studi Akuakultur, Fakultas Pertanian, Universitas Djuanda Bogor \\ Jalan Tol. Ciawi 1, Kotak Pos 35, Bogor - 16720 \\ Email: wahyuhidayat@gmail.com
}

\begin{abstract}
This study aims to identify and inventory the ectoparasites and prevalence of ectoparasites on catfish (Clarias gariepinus) fry are cultivated at the subdistrict Ciawi, Bogor. The method has been used in the research was been taken catfish fry from 10 fish farmers at subdstrict Ciawi and 10 fish/pond. Mucus, gills and fins of fish had been observed under the microscope binocular to identify the ectoparasites according to the key book of fish parasites. The result of the research showed that the ectoparasites that infect the catfish fry at the subdistrict Ciawi, Bogor were Trichodina sp., Dactylogyrus sp., And Vorticella sp. Prevalence of ectoparasites were Trichodina sp. 11 - 41\%, Dactylogyrus sp. 5-38\%, and Vorticella sp. 0-20\%.
\end{abstract}

Keywords: ectoparasites, catfish fry, prevalence

\begin{abstract}
ABSTRAK
Penelitian ini bertujuan untuk mengidentifikasi dan inventarisasi jenis dan prevalensi ektoparasit pada benih ikan lele Sangkuriang (Clarias gariepinus) yang dibudidayakan di Kecamatan Ciawi Kabupaten Bogor. Metode penelitian yang digunakan adalah dengan mengambil benih ikan lele Sangkuriang dari 10 pembudidaya ikan lele Sangkuriang di KecamatanCiawi, yang tersebar di Desa Pandan Sari, Desa Jambuluwuk dan Desa Bojongmurni. Dari setiap pembudidaya ikan diambil sample sebanyak 10 ekor/kolam. Lendir, insang dan sirip ikan uji diperiksa dibawah mikroskop binokuler dan jenis ektoparasit diidentifikasi menggunakan buku kunci identifikasi parasit ikan. Hasil penelitian ini memperlihatkan bahwa ektoparasit yang menginfeksi benih ikan lele Sangkuriang yang berasal dari Kecamatan Ciawi, Kabupaten Bogor adalah Trichodina sp., Dactylogyrus sp., dan Vorticellasp. Prevalensi masing-masing ektoparasit adalah Trichodina sp. 11-41\%, Dactylogyrus sp. 5-38\% dan Vorticella sp. 0-20\%.
\end{abstract}

Kata kunci: ektoparasit, benih ikan lele Sangkuriang, prevalensi

Wahyu Hidayat, Mulyana, Fia Sri Mumpuni. 2020. Inventarisasi Ektoparasit Pada Benih Ikan Lele Sangkuriang (Clarias gariepinus). Jurnal Mina Sains 6(1): 28-32.

\section{PENDAHULUAN}

Pengembangan dan keberlanjutan kegiatan budidaya ikan air tawar sering menghadapi kendala. Salah satunya adalah bila terjadi serangan penyakit, baik penyakit infeksi maupun non infeksi.Virus, bakteri, jamur, protozoa maupun parasit merupakan golongan penyakit infeksi sedangkan penyakit non infeksi yang disebabkan oleh lingkungan, pakan, genetik dan tumor (Aryani dkk. 2004). Penularan penyakit dan parasit dapat melalui beberapa mekanisme antara lain melalui kontak langsung antara ikan sakit dan ikan sehat, bangkai ikan sakit melalui air, penularan ini biasa terjadi pada satu kolam budidaya. Mekanisme penularan lainnya adalah melalui peralatan dan melalui pemindahan ikan dari daerah wabah ke daerah yang bukan wabah (Sunarto, 2005).

Salah satu ikan air tawar yang sangat potensial untuk dikembangkan menjadi produk unggulan perikanan budidaya adalah ikan lele Sangkuriang (Clarias gariepinus). Ikan lele Sangkuriang sebagai komoditi perikanan memiliki beberapa keunggulan baik dari aspek ekonomi, budidaya maupun kelestarian lingkungan. Ikan lele Sangkuriang merupakan salah satu ikan budidaya air tawar yang mempunyai prospek masa depan yang cerah. Ikan ini mempunyai banyak keunggulan, diantaranya 
pemeliharaannya mudah, pertumbuhannya cepat, rasa dagingnya khas, dan harganya cukup tinggi (Arie, 1999).

Tujuan dari penelitian ini adalah untukmengetahui jenis ektoparasit dan prevalensinya pada benih ikan lele Sangkuriang (Clarias gariepinus).

\section{METODOLOGI PENELITIAN}

\section{Waktu dan Tempat}

Penelitian ini dilaksanakan pada bulan Oktober 2015-Juni 2016, bertempat di Laboratorium Perikanan, Universitas Djuanda Bogor.

\section{Alat dan Bahan}

Bahan yang digunakan pada penelitian ini adalah ikan lele Sangkuriang (Clarias gariepinus) sebagai objek penelitian yang dibeli dari pembudidaya ikan lele Sangkuriang di Kecamatan Ciawi, Kabupaten Bogor. Bahan lain yang digunakan adalah akuades, bahan-bahan kimia, reagent-reagent serta indikator untuk titrasi DO.

Alat yang digunakan pada penelitian ini adalah alat bedah (gunting, pisau), kaca obyek, kaca tutup, papan bedah, pipet tetes, thermometer, $\mathrm{pH}$-meter, spectrometer, alatalat titrasi DO, dan mikroskop binokuler stemi $2000 \mathrm{C}$.

\section{Metode Penelitian}

Pengambilan sampel dilakukan dengan cara sebagai berikut: pertama datang ke pembudidaya ikan di Kecamatan Ciawi, Kabupaten Bogor untuk mengambil sampel. Dari total pembudidaya ikan lele Sangkuriang, diambil data $10-15 \%$ sebagai objek pengambilan sampel. Ikan lele
Sangkuriang yang digunakan dalam pengambilan sampel adalah 5-10 ekor/kolam/pembudidaya selanjutnya ikan diangkut ke Laboratorium Perikanan Universitas Djuanda untuk diperiksa dan dianalisis jenis ektoparasit dan prevalensinya. Prosedur pemeriksaan ektoparasit dilakukan dengan cara: mula-mula lendir ikan dikerik dari permukaan tubuh. Insang dan siripikan lele Sangkuriang dikerik menggunakan pisau bedah kemudian diletakkan di atas kaca objek yang berbeda dan ditambahkan setetes akuades, lalu ditutup menggunakan kaca tutup. Preparat ini lalu diperiksa di bawah mikroskop bimokuler pada pembesaran 100x untuk mengamati dan menganalisis jenis ektoparasit dan prevalensinya.

Prevalensi tiap jenis ektoparasit yang menginfeksi benih ikan lele Sangkuriang dihitung menggunakan rumus sebagai berikut:

$$
\text { Prevalensi }=\frac{\sum \text { ikanyangterinfeksi }}{\sum \text { ikanyangdiperiksa }} X 100 \%
$$

\section{HASIL DAN PEMBAHASAN}

\section{Hasil}

Hasil penelitian terhadap benih ikan lele Sangkuriang yang berasal dari pembudidaya ikan lele Sangkuriang Kecamatan Ciawi Kabupaten Bogor didapatkan jenis-jenis ektoparasit yang menginfestasi ikan yaitu: Trichodina sp., Dactylogyrus sp. dan Vorticella sp.

Prevalensi tiap jenis ektoparasit pada ikan lele Sangkuriang di masing-masing lokasi pengambilan dicantumkan pada Tabel 1 di bawah ini.

Tabel 1 Prevalensi (\%) Ektoparasit pada Ikan Lele Sangkuriang di Kecamatan Ciawi Kabupaten Bogor

\begin{tabular}{lccc}
\hline Jenis & \multicolumn{3}{c}{ Desa } \\
\cline { 2 - 4 } Ektoparasit & Pandan Sari & Jambuluwuk & Bojongmurni \\
\hline Trichodina sp. & 41 & 11 & 30 \\
Dactylogyrus sp. & 38 & 5 & 29 \\
Vorticella sp. & 20 & 0 & 10 \\
\hline
\end{tabular}


Hasil pengamatan ektoparasit pada ikan lele Sangkuriang berdasarkan bagian tubuh ikan yang terinfeksi sebagaimana Tabel 2 dan hasil pengukuran kualitas air selama penelitian dicamtumkan pada Tabel 3 .

\section{Pembahasan}

Dari hasil penelitian yang dilakukan didapatkan tiga jenis ektoparasit yang menginfeksi ikan lele Sangkuriang Clarias gariepinus di Kecamatan Ciawi Kabupaten Bogor (Desa Pandan Sari, Desa Jambuluwuk dan Desa Bojongmurni), yaitu Trichodina sp, Vorticella sp, dan Dactylogyrus sp. Dari hasil pemeriksaan didapat nilai prevalensi parasit beserta habitat masing-masing parasit.

Tabel 2 Prevalensi (\%) Ektoparasit pada Lendir, Insang dan Sirip Ikan

\begin{tabular}{lccc}
\hline Jenis & \multicolumn{3}{c}{ Target } \\
\cline { 2 - 4 } Ektoparasit & Lendir & Insang & Sirip \\
\hline Trichodina sp. & 60 & 7 & 15 \\
Dactylogyrus sp. & 12 & 60 & 0 \\
Vorticella sp. & 18 & 0 & 12 \\
\hline
\end{tabular}

Dari jenis-jenis ektoparasit tersebut yang paling banyak menginfeksi ikan lele Sangkuriang adalah Trichodina sp. Berdasarkan hasil penelitian, diketahui bahwa prevalensi Trichodina sp. yang ditemukan pada tiga lokasi sampling berkisar antara $11-41 \%$, prevalensi Dactylogyrus sp. 5-38\% dan Vorticella sp. 0-20\% (Tabel 1).

Dari hasil pengamatan yang didapatkan sebagaimana pada Tabel 1 untuk ikan lele Sangkuriang yang diambil dari 3 (tiga) desa di Kecamatan Ciawi Kabupaten Bogor, didapatkan bahwa prevalensi ektoparasit yang menyerang paling tinggi ada di desa Pandan Sari. Ada beberapa hal yang menyebabkan hal ini, diantaranya adalah para pembudidaya ikan lele Sangkuriang di desa Pandan Sari menggunakan bibit yang berasal dari daerah lain. Sedangkan di desa Jambuluwuk dan desa Bojongmurni menggunakan bibit dari hasil pembenihan sendiri. Ikan yang berasal dari daerah lain tersebut memiliki peluang membawa bibit penyakit dari daerah asalnya.

Selain bibit yang berasal dari luar, kondisi kolam tempat pemeliharaan ikan lele
Sangkuriang yang berada di Desa Pandan Sari kebanyakan terbuka dan dekat dengan saluran pembuangan rumah tangga, sehingga kolam sangat rentan terkontaminasi oleh air yang berasal dari luar.

Menurut Zafran (1997), distribusi parasit pada organ penempelnya dipengaruhi oleh suhu, kelembaban, sifat kimia media sekelilingnya dan persediaan makanan pada tubuh inang. Perbedaan dalam sistem budidaya masing-masing daerah juga mempengaruhi jenis parasit yang menginfeksi ikan dari daerah tersebut. Bahkan vektor berupa pakan alami juga bisa menjadi perantara bagi parasit.

Ikan lele Sangkuriang yang berasal dari Desa Pandan Sari dan Desa Bojongmurni dipelihara menggunakan sumber air yang berasal dari sungai,dan yang satu lokasi lagi sumber air pemeliharaan di Desa Jambuluwuk berasal dari air sumur. Sumber air yang digunakan dapat menjadi pembawa atau vektor bagi parasit untuk menginfeksi ikan karena tidak dilakukan penyaringan sebelumnya.

Tabel 3 Kualitas Air Kolam di Masing-Masing Lokasi Pengambilan Sampel

\begin{tabular}{lccc}
\hline Kualitas air & $\begin{array}{c}\text { Desa Pandan } \\
\text { Sari }\end{array}$ & $\begin{array}{c}\text { Desa } \\
\text { Jambuluwuk }\end{array}$ & $\begin{array}{c}\text { Desa } \\
\text { Bojongmurni }\end{array}$ \\
\hline Suhu $\left({ }^{\circ} \mathrm{C}\right)$ & 29,4 & 28,0 & 28,2 \\
pH & 6,72 & 6,24 & 6,40 \\
DO $(\mathrm{ppm})$ & 2,83 & 2,06 & 2,94 \\
\hline
\end{tabular}


Penggunaan sumber air di ketiga desa tersebut sangat mempengaruhi keberadaan dan jenis parasit yang menginfeksi ikan lele Sangkuriang. Buruknya sumber air yang digunakan oleh para pembudidaya dapat dilihat dari jumlah jenis parasit dan prevalensi parasit. Menurut (Bahrudin, 1994). Semakin buruk sumber air yang digunakan memungkinkan semakin beragamnya ektoparasit yang menginfeksi. Tingginya nilai prevalensi parasit yang menginfestasi bagian lendir ini karena permukaan tubuh ikan merupakan bagian yang pertama kali kontak dengan lingkungan. Dengan kata lain lendir yang di permukaan tubuh merupakan jalan masuk bagi parasit ke dalam tubuh ikan (Pramono, 2008).

Trichodina banyak menyerang lendir ikan karenaJenis parasit ini dan tingkat infeksi parasit dipengaruhi oleh berbagai hal, mulai dari faktor lingkungan hingga sistem imun, distribusi parasit pada organ penempelanya dipengaruhi oleh suhu, kelembapan, sifat kimia media sekelilingnya, dan persedian makanan pada tubuh inang. Selain itu perbedaan dalam sistem budidaya pada masing-masing daerah dan vektor berupa pakan alami yang menjadi perantara bagi parasit juga mempengaruhi jenis parasit yang menginfeksi (Kordi, 2004).

Setiap jenis parasit mempunyai habitat yang berbeda pada organ inang sebagai tempat hidupnya, namun ada beberapa ektoparasit yang menginfeksi dua atau lebih organ tubuh inangnya, seperti Trichodina sp. yang dapat menginfeksi sisik, kulit, sirip dan insang (Hardiroseyani, 2006). Infeksi Trichodina sp. dapat menyebabkan iritasi yang disebabkan oleh penempelan cawan adesifnya. Dalam intensitas yang tinggi, parasit ini dapat menyebabkan kerusakan yang serius pada sel epidermal inangnya. Pada kondisi tersebut, Trichodina sp. bertindak sebagai ektoparasit sejati yang memakan sel rusak dan dapat menembus masuk ke dalam insang dan jaringan kulit inangnya. Penyebaran Trichodina sp. terjadi melalui kontak langsung dengan ikan atau air yang terkontaminasi (secara horizontal) (Handajani, 2005). Dactylogyrus banyak menyerang insang karena memang organ targen parasit Dactylogyrus adalah menyerang bagian insang saja Dactylogyrus sp. merupakan salah satu spesies yang tergolong dalam ordo Monogenea. Parasit ini dapat diidentifikasi berdasarkan dua pasang bintik mata dan empat tonjolan yang terdapat pada bagian anterior dan 14 kait marginal parasit ini dapat ditemukan pada bagian insang, permukaan tubuh dan sirip (Pramono, 2008).

Gejala klinis yang lain yang tampak adalah:insang ikan rusak, luka dan timbul perdarahan, kulit berlendir dan berwarna pucat, ikan lebih sering mengambang di permukaan kolam, hilangnya nafsu makan, lethargi, meningkatnya gerak pernafasan, tampak mukus berwarna keputihan yang menyelubungi insang, infeksi Dactylogyrus pada insang akan menyebabkan perubahan warna pada insang, di mana insang tertutup oleh mucus berwarna keputihan. Selain itu, insang akan mengalami kerusakan dan perdarahan akibat menempelnya mulut Dactylogyrus. Insang biasanya akan membengkak yang ditandai dengan penonjolan operkulum (Rukmono, 1998). Vorticella sangat kecil prevalensi karena Vorticella sp. merupakan protozoa dari filum Ciliophora. Vorticella sp. tidak hanya hidup di perairan air tawar saja, tetapi juga di perairan laut dan dapat menempel pada tumbuhan dan hewan (Kabata, 1985). Vorticella yang diidentifikasi dari ikan lele Sangkuriang berasal dari sirip dan permukaan tubuh. Parasit ini memiliki ciri bentuk yang khas, adoral membran yang bergerak membuka dan menutup seperti rambut getar, tangkai yang berfungsi untuk menempel pada organ atau substrat dan memiliki makronukleus (Purbomartono, 2010).

Parasit yang satu ini tidak memiliki percabangan maupun tidak dalam bentuk koloni, Vorticella memiliki 1 individu tiap tangkainya, berkembang biak dengan cara bertunas dan konjugasi. Konjugasi 
merupakan reproduksi seksual dari Vorticella yaitu dengan cara dengan menyisipkan DNA pada individu yang lain (Martiadi, 2002).

Gejala klinis parasit Vorticella sp. adalah daerah terserang parasit terlihat jelas dalam bentuk bintil ke abu-abuan pada kulit, banyak memproduksi lendir, menggosok-gosokkan tubuh ke dinding bak atau jurang. Efek pada inang menimbulkan infeksi sekunder bakteri maupun jamur (Bunga, 2008).

\section{KESIMPULAN DAN SARAN}

\section{Kesimpulan}

Hasil penelitian inventarisasi ektoparasit pada benih ikan lele Sangkuriang (Clarias gariepinus) di Kecamatan Ciawi Kabupaten Bogor didapatkan jenis ektoparasit yang menginfeksi adalah Trichodina sp., Dactylogyrus sp., dan Vorticella sp. Prevalensi masing-masing ektoparasit adalah Trichodina sp. 11- 41\%, Dactylogyrus sp. 5$38 \%$ dan Vorticella sp. 0-20\%.

\section{Saran}

Untuk melengkapi hasil inventarisasi ektoparasit pada benih ikan lele Sangkuriang di Kecamatan Ciawi perlu dilakukan juga terhadap induk ikan lele Sangkuriang. Dengan hasil inventarisasi terhadap induk ikan lele Sangkuriang maka dapat dilakukan tindakan pencegahan agar tidak terjadi penularan dari induk kepada anaknya.

\section{DAFTAR PUSTAKA}

Arie U. 1999. Membenihkan Ikan Lele Dumbo. Balai Budidaya Air Tawar (BBAT). Sukabumi.

Aryani N., Henny S, Iesje L, Morina R.2004. Parasit dan Penyakit Ikan. Pekanbaru: Unair Press.

Bahrudin AS. 1994. Ektoparasit pada Ikan Seribu (Poecilia reticulatus Peters), dari Kolam dan Sungai di Desa Hegarmanah, Kecamatan Cikeruh, Kabupaten Sumedang, Jawa Barat. Jurnal Agrikultura 5(1): 81-90.

Bunga, M. 2008. Prevalensi dan Intensitas Serangan Parasit Diplectanum sp. pada
Insang Ikan Kerapu Macan (Epinephelus fuscoguttatus Forsskal) diKeramba Jaring Apung. Jurnal Ilmu Kelautan dan Perikanan18 (3): 204210.

Hadiroseyani Y., Hariyadi P, Nuryati S. 2006. Inventarisasi Parasit Lele Dumbo Clarias sp. di Daerah Bogor. Jurnal Akuakultur Indonesia 5(2): 167177.

Handajani H. 2005. Parasit dan Penyakit Ikan. Malang: UMM Press.

Kabata Z. 1985. Parasites and Diseases of Fish Cultured in the Tropics. London: Taylor and Prancis.

Kordi KMGH. 2004. Pengelolaan Kualitas Air dalam Budidaya Perairan. Jakarta: Rineka Cipta.

Martiadi R. 2002. Inventarisasi Parasit Pada Ikan Maanvis, Ikan Black Ghost dan Ikan Neon Tetra di Daerah Jakarta Selatan, DKI Jakarta. Skripsi. Prodi Budidaya Perairan. FPIK IPB.Bogor.

Pramono TB.Syakuri H. 2008. Infeksi Parasit Pada Permukaan Tubuh Ikan Nilem (Osteochilus hasellti) yang Diperdagangkan di PPI Purbalingga. Jurnal Berkala Ilmiah Perikanan 3 (2): $79-82$.

Purbomartono C. 2010. Identify of Helminth and Crustacean Ectoparasites on Puntius javanicus Fry at Local Hatchery Center Sidabowa and Kutasari. Sains Akuatik 10(2): 134140.

Rukmono D. 1998. Berbagai Jenis Parasit Yang Menyerang Ikan Hias Pemeriksaan Laboratorium Karantina Ikan Ngurah Rai-Denpasar, Bali.

Sunarto A. 2005.Epidemiologi Penyakit Koi Herpes Virus (KHV) di Indonesia. Pusat Riset Perikanan Budidaya. Jakarta.

Zafran I. Koesharyani, Yuasa K. 1997. Parasit Pada Ikan Kerapu di Panti Benih dan Upaya Penanggulangannya. Jurnal Penelitian Perikanan Indonesia3 (4):16-23. 